\title{
The Application of New Media in Ideological and Political Education in Colleges
}

\author{
Kun Huang \\ Hubei Polytechnic Institute, Xiaogan, Hubei, 432000
}

Keywords: Ideological and Political Education, New Media, Application.

\begin{abstract}
New media is a relative concept, the new media in today's society refers to the network technology and digital technology to support the information dissemination system. New media is characterized by digital, interactive and personalized. As the technology maturity is high, the cost is declining, the new media has become the mainstream of the contemporary media, the mastery of the new media has become the prerequisite for the success of all walks of life.
\end{abstract}

\section{Introduction}

College students are the hope of the nation, the future of the motherland, colleges and universities is to cultivate the cause of socialism builders and successors of the main positions. The party and the state have always attached great importance to the ideological and political education in colleges and universities. On the basis of inheriting the fine tradition, the party and the society have paid attention to the new situation and new problems of the ideological and political education in colleges and universities, and constantly strengthened and improved the ideological and political education work for college students. In the ideological and political education work in colleges and universities, explicit education is still the main channel, mainly in the form of theoretical indoctrination. Compared with explicit education, recessive education has a unique advantage. Implicit education, also known as unconscious education, is relative to conscious education, is a kind of education that is not perceived by the educator itself. Chinese scholars believe that hidden education has obvious ideological and political education function, combined with ideological and political education, defined as ideological and political education. Ideological and political education in colleges and universities is the use of college students loved the means, entertaining, entertaining, enlightenment in the environment, the ideological and political education throughout them, so that students in the subtle influence of education. This method can be a good way to eliminate the rebellious psychology of college students, greatly meet the psychological needs of college students equal, can achieve more effective educational results. However, the operation of ideological and political education in colleges and universities is still a weak link, for its theoretical research is still lagging behind, the practical use of the area has not been given enough attention.

\section{New Media and Its Influence on Ideological and Political Education in Colleges}

New media is in the information technology, micro-manufacturing technology, human software support under the media form, including digital magazines, digital newspapers, digital broadcasting, mobile phone text messages, mobile TV, digital TV, digital cinema, touch media. Relative to the press, outdoor, radio, television four traditional sense of the media, the new media is vividly known as the "fifth media." "New" and "old", "modern" and "traditional" are always relatively speaking, the media are the same old and new. With Cai Lun invented papermaking, paper media appeared. And the paper media has also created a great glory, according to historical records, the Eastern Han Dynasty left to write a gorgeous article called "Tokyo Fu", even lead to a serious shortage of paper and make the price of paper rose sharply, leaving the "Luoyang paper expensive" s legend. In the Han Dynasty, China was born the world's first newspaper - "Di Bao", compared with the way the past word of mouth, obviously "Di Bao" can also be called a new media system. In 1920 the birth of 
the world's first radio station, in 1926 in Britain, the birth of the first TV, and the past compared to the newspaper, apparently radio and television is a very new new media. With the reform of science and technology, the production and dissemination of human information has also changed.

New media brings good and mixed information resources. New media for college students to provide massive, rich, complex and even chaotic information resources, these information varies greatly, positive and negative staggered, sediment, mixed with multiple values. The judgment of college students has certain limitations. In this environment, the thinking of college students has been affected constantly, and the values and ways of thinking have never been tested. And hidden ideological and political education has a hidden, do not directly tell the education content of educators, but the education content hidden in the activities associated with the environment or the

carrier. In the face of the mixed information resources of the new media burdock, the hidden ideological and political education in colleges and universities should consider how to penetrate the main melody and how to guide the students to choose and utilize the new media resources perfectly.

Virtual new media environment leads to over-reliance on college students. Under the new media environment, there are some virtual activities, college students can hide their identity in the case of browsing and publishing information, part of the college students over-reliance on new media, swim in a variety of new media more and more time to participate in school Cultural activities of the time less and less, gradually out of the reality of college life, resulting in college students concerned about the issue more and more satisfied with the new media access to some of the surface information, and gradually lost the important things for a profound rational thinking ability. The ideological and political education emphasizes the consciousness and unconscious participation of college students, and the virtual nature of the new media environment leads students to over-reliance on the new media, which brings some obstacles to the ideological and political education.

New media on the invisible ideological and political education workers put forward new requirements. Ideological and political education is a "teaching and learning" process, is no longer a traditional one-way education model, educators are the main body, the implementation of educational activities, in some cases can also be converted into ideological and political education object. New media technology said the new moon, college students active thinking, the new technology has a keen insight and advanced control. Therefore, the new media environment, the implementation of ideological and political education workers not only have a firm political stance, a solid theoretical basis, but also a democratic and equal education concept and a comprehensive new media knowledge and the use of new media to carry out ideological and political education Ability. This requires the ideological and political education workers must have the appropriate new media technology, proficient in the application of new media, know how to use new media and development of fine silent ideological and political education.

\section{The Necessity of New Media Applied to Ideological and Political Education in Colleges}

China's rapid development of new media, penetrate the whole society. With the maturity of China's information technology, the rapid development of new media, and its personalized, vivid, convenient and rich information and other characteristics quickly have a large number of users, to penetrate into all aspects of people's social life. At present, China's new media technology has been more mature, new media communication required for a variety of hardware and software development, a variety of end products continue to introduce new technology, some technology has been close to the international advanced level. In recent years, China's new media and related industries flourished, the use of new media groups continue to expand. To the development of new media network, for example, as of the end of June 2012, the number of Chinese Internet users reached 5.38 billion, the Internet penetration rate of 39.9\%. In the 3G technology support, Andrews system, Apple's mobile phone to make China's mobile phone users continue to expand the scale. Mobile digital TV, mobile network terminals are also slowly appear in the streets, buses and taxis, quietly into people's lives. A variety of new media technology continues to introduce new, will give our new media development has brought unlimited opportunities. At the same time, the new media 
greatly changed the mode of human information transmission, affecting the organization of human knowledge, transmission and access, but also affect people's way of thinking, way of life and work, and this new way of life and work recognized and accepted, which will have a profound impact on China's cultural life.

At the present stage of China, ideological and political education is the practice of the party to educate the people with the Marxist ideology and theory system, the communist faith and the socialist moral standard. The aim is to improve the people's ideological and moral qualities and inspire the people to practice the socialist modernization drive The To achieve the purpose of ideological and political education, educators will choose a certain form of education to carry out educational activities, these forms is the carrier of ideological and political education. The so-called ideological and political education carrier, refers to the implementation of ideological and political education activities in the process, able to carry and disseminate ideological and political education content or information can be used for ideological and political education theme, and the subject can interact with an activity Form or substance entity. Text, language, conference, theoretical study, conversation, spiritual civilization to create activities, mass communication, cultural construction, etc., can become a form of ideological and political education activities, that is, the carrier of ideological and political education. For example, in the practice of ideological and political education in colleges and universities, those who can carry and transmit in line with China's social development of political views, ideas, moral norms and legal norms and other knowledge and information activities of the form or object, are the ideological and political education carrier The Educators and college students through the ideological and political education carrier interactive activities, so as to achieve a certain ideological and political education purposes.

\section{The Application of New Media in Ideological and Political Education in Colleges and Universities}

Campus network as a modern university student information platform, carrying the actual campus life of college students, learning information, college students have a great attraction. The party and the state have always attached great importance to the work of ideological and political education on the Internet, and have introduced relevant policies and regulations. Colleges and universities have made some remarkable achievements in the ideological and political education work. However, the traditional ideological and political education "red" website, the transmission of information is too obvious, the intensity is too large, will cause the choice of college students is limited, easily lead to college students on the site of the conflict and exclusion. Therefore, while strengthening the construction of the campus network at the same time, university workers must adhere to the principle of permeability, make full use of the network of virtual, hidden and interactive features, extend the campus network of hidden education, hidden ideological and political education content and purpose.

First of all, to strengthen the construction of campus sites, reflecting the permeability. Colleges and universities in the construction of a good campus ideological and political education on the theme of the site at the same time, we must consciously create a good campus network link page, infiltration of ideological and political education content and purpose. For example, on the campus network to introduce school history alumni, show school appearance; publicity good people, play an example role; record campus cultural activities, show the spirit of college students. In this way, college students in the campus network, the unconscious by the ideological and political education, training students good ideas, personality and moral character, to help them establish a correct world outlook, outlook on life and values, so as to form a good style of study, school spirit.

Second, strengthen the campus network content construction, reflecting the service. College students pay more attention to their own learning and life is closely related to the knowledge and information, therefore, the contents of the campus site to fit the actual needs of college students, adhere to close to the students, close to life and close to the principle of reality, with a clear ideological content and rich Of the information resources to attract the attention of college students, and enhance the attractiveness of the campus site and appeal. Through the establishment and 
opening of a variety of web pages, in a vivid, popular way, for college students to provide rich, comprehensive, readable content to meet the needs of college students.

Once again, set up a campus network exchange platform, reflecting the interaction. In the campus network, should create some close to the campus and teachers and students of the exchange site, give full play to the network of new media equal interactive advantages for teachers and students and students to provide a pleasant atmosphere between the exchange platform, gives full play to its hidden education Function. For example, the campus BBS forum (electronic bulletin board system), campus microblogging and blog, mental health guidance network, which have become college workers design and implementation of ideological and political education exchange tool. University workers should always pay attention to the dynamic development of network technology, for the first time the popular network communication tools to move to the campus site, firmly grasp the initiative.

Finally, update the contents of the campus website, reflecting the timeliness. Compared with the traditional media, the biggest advantage of the network is the content and form has a very fast update speed, many sites on the content, almost every day update, and even updated from time to time, which is to improve the site click rate one of the main factors. The campus website should also adapt to this advantage, update the content of the website in time, and express the information content in the form of graphic and dynamic combination, stimulate the interest of college students, promote the positive reading and active participation of college students, expand the influence of the website to improve the students Autonomy in Ideological and Political Education.

\section{References}

[1] Zhong Liang. Problems and Countermeasures of Ideological and Political Education in Colleges and Universities [J] .New West (Theoretical Edition), 2017 (12)

[2] Cheng Caixiu. On the "around the students" to create ideological and political education work [J] .New West (theoretical), 2017 (12)

[3] and Ya Qin, Zhang Jia-yin. Ideological and political education work team construction [J]. Modern communication, 2017 (14)

[4] Wang Jiajia. Ideological and political education in colleges and universities and the method of research [J]. Modern communication, 2017 (12)

[5] Zhang Ye. On the Ideological and Political Education of College Students - How to Promote the Ideological and Political Education of the University through the Construction of Counselors [J]. Management Managers, 2017 (18) 